\title{
Echocardiographic ultrasound screening assessment of the circulatory system of newborns delivered at basic level perinatal care centers
}

\author{
Joanna Kukawczynska-Noczynska, ${ }^{1, A, C, D}$, Rita Suchanska ${ }^{2, B}$, Marta Berghausen-Mazur2,B,E \\ ${ }^{1} 1^{\text {st }}$ Department and Clinic of Pediatrics, Allergology and Cardiology, Wroclaw Medical University, Poland \\ 2 st Department and Clinic of Gynaecology and Obstetrics, Wroclaw Medical University, Poland \\ A - research concept and design; $B$ - collection and/or assembly of data; $C$ - data analysis and interpretation; \\ $D$ - writing the article; $E$ - critical revision of the article; $F$ - final approval of the article
}

Address for correspondence Joanna Kukawczynska-Noczynska

E-mail: jo.ku@wp.pl

Funding sources

None declared

Conflict of interest

None declared

Received on May 31, 2018

Reviewed on August 30, 2018

Accepted on September 27, 2019

Published online on December 17, 2019

Cite as

Kukawczynska-Noczynska J, Suchanska S, BerghausenMazur M. Echocardiographic ultrasound screening assessment of the circulatory system of newborns delivered at basic level perinatal care centers. Adv Clin Exp Med. 2019;28(12):1691-1695. doi:10.17219/acem/110327

DOI

10.17219/acem/110327

Copyright

Copyright by Author(s)

This is an article distributed under the terms of the

Creative Commons Attribution Non-Commercial License

(http://creativecommons.org/licenses/by-nc-nd/4.0/)

\begin{abstract}
Background. For many years standards of medical care for newborns have been created and perfected with the goal of improving care, including early detection of congenital defects.

Objectives. The objective of the study was to assess the circulatory system in newborns born at basic level of perinatal care centers and the comparison of specific parameters of cardiac function and structure according to the method of birth, body mass, sex, Apgar score, pulse oximetry results, and presence of other pathologies.

Material and methods. The study was carried out in 255 newborns aged 3-14 days. The children were assessed according to Apgar score, were weighed and pulse oximetry testing was carried out, and symptoms of neonatal jaundice or infection were taken into account. Each child was subjected to a physical examination and echocardiographic examination.

Results. Among the group studied, 3.5\% of children had defects of the circulatory system and functional disorders.

Conclusions. Pulse oximetry testing, due to its low level of invasiveness, high sensitivity and specificity, low cost and repeatability, should be used as the primary screening test, allowing for early detection of critical congenital heart defects (CHDs). It should be stressed that the test should be repeated before discharge of newborns from the neonatology department so as to avoid missing CHDs which are asymptomatic or mute at birth. Morphological and functional assessment of specific structures of the heart in delivered newborns showed correlation of the size of the left ventricle (LV) with body mass. The remaining factors, such as method of delivery, sex, neonatal jaundice, and audible murmur, were irrelevant. Routine cardiological assessment of healthy newborns is therefore not necessary.
\end{abstract}

Key words: congenital heart defect, echocardiography, newborn 
For many years standards of medical care for newborns have been created and perfected with the goal of improving such care, including early detection of congenital defects. Currently, according to the newest guidelines of care, each newborn is to be assessed along a schedule of screening tests carried out in the neonatology department. Screening tests are a form of prophylaxis, allowing for early diagnosis of congenital diseases before they become symptomatic. Currently, the number of prophylactic screening tests in Poland stands at 27 in addition to auditory assessment and pulse oximetry. ${ }^{1}$ The social and economic benefits of screening tests are unquestionable. Between the year 2009 and 2013 in Poland, according to data presented by the Ministry of Health, on the basis of screening tests, 1,394 congenital diseases were diagnosed. ${ }^{1}$ The frequency of congenital heart defects (CHDs) in the population is around $0.8-1 \%$, of which $25 \%$ can be considered critical defects requiring urgent surgical or hemodynamic intervention. ${ }^{2,3}$ Newborns with serious complex heart defects may at first present atypically, without any obvious symptoms of cardiac insufficiency. Typically, the stay for neonates in the neonatology department is short and as a result newborns with undiagnosed cardiac defects are at high risk of death after discharge from the hospital. ${ }^{4}$ The advances in ultrasonography, including fetal echocardiography, have resulted in increased early detection of many fetal defects and the referral of pregnant women to deliver in the $3^{\text {rd }}$ highest level of perinatal care units, assuring optimal medical care for such newborns. ${ }^{5}$

It is assumed that newborns delivered in basic level perinatal care units lack prenatal diagnoses indicating potential complications. From the source data it can be concluded that, despite intense improvements and advances in ultrasonography techniques, many heart defects are still not diagnosed until after delivery ${ }^{6,7}$ Pulse oximetry in neonatal units, which currently is regarded as a valuable tool in the early diagnosis of $\mathrm{CHD}$, has been recommended and implemented for several years. ${ }^{8}$ According to Thangaratinam et al., the sensitivity of the test is estimated at $76.5 \%$ with a specificity of $99.9 \% .{ }^{9}$ The percentage of false positive results is only $0.14 \%$.

\section{Objectives}

The objective of the study was an assessment of the circulatory system in newborns born at basic level of regional perinatal care centers through physical as well as echocardiographic testing, and determination of the number and types of heart defects as well as other circulatory system abnormalities detected in the population studied.

Additionally, another goal of the study was to compare specific parameters of cardiac function and structure taking into account the method of birth, body mass of the newborn, sex, Apgar score, pulse oximetry results, and presence of other pathologies associated with the neonatal phase, such as congenital infection, heart murmur or neonatal jaundice.

\section{Material and methods}

The study was carried out on 255 newborns aged 3-14 days, born in a basic level of perinatal care unit during a 12-month period in 2014-2015. Children born in a regional hospital in Środa Śląska were assessed in the neonatology department according to Apgar score at $1 \mathrm{~min}, 3 \mathrm{~min}, 5 \mathrm{~min}$, and $10 \mathrm{~min}$ of life. The newborns were weighed and pulse oximetry testing was carried out $2-24 \mathrm{~h}$ after birth as well as on the day of discharge. When symptoms of neonatal jaundice presented, levels of bilirubin were monitored and with symptoms of infection, the appropriate therapeutic treatment was administered.

The examination assessing the circulatory system was carried out in an ambulatory setting in the cardiology clinic 3-14 days after birth. Each child was subjected to a physical examination which assessed the heart tones, rhythm and rate of the heart as well as the peripheral pulse. Each subject also received an echocardiographic examination which assessed the specific parameters of heart function and structure as well as the morphology of the heart and the presence of structures from prenatal life - patent foramen ovale (PFO) and patent ductus arteriosus (PDA). In the M-Mode, measurements of the right ventricle in diastole (RVED) as well as the left ventricle in diastole (LVED) and systole (LVES) were carried out. The shortening fraction (FS) and ejection fraction for the left ventricle (LVEF) were measured, and the contractile function of the right ventricle (RV) was assessed through tricuspid annular plane systolic excursion (TAPSE); the velocity of flow on the aortic (AoV) and pulmonary valve (PV) as well as flow acceleration time (pulmAT - pulmonary acceleration time) were measured to assess the characteristics of diastolic flow on the mitral valve (MVE - mitral valve velocity flow in early diastole and MVA - mitral valve velocity flow in late diastole).

The statistical analysis was carried out utilizing quantity as well as quality parameters of statistical description. In our work, we used quantitative variables such as mean and standard deviation (SD) and quality variables such as populations of chosen subgroups and percentages showing prevalence of specific characters in subgroups. Correlations between cardiological parameters and quantitative parameters were specified using Spearman's correlation coefficient, while quality parameters were examined with Wilcoxon's test or Fisher's exact test.

\section{Results}

\section{Characteristics of the population studied}

Briefly, $47.4 \%$ of children studied were male while $52.6 \%$ were female. Those born naturally comprised $51.4 \%$ while those born through caesarean section were $48.6 \%$ of the population. The birth weight varied from 
$2,110 \mathrm{~g}$ to $6,000 \mathrm{~g}$ with the average being 3,578 g. Broken down by sex, the average mass of females was $3,678 \mathrm{~g}$ while for males it was 3,482 g. The registered Apgar scores after $1 \mathrm{~min}$ and $5 \mathrm{~min}$ showed a great deal of uniformity. Average Apgar score after 1 min was 9 (min. 2 points, max. 10 points). Assessed at $5 \mathrm{~min}$, the Apgar score for nearly all newborns was 10 .

Pulse oximetry was carried out twice, with a score of equal to or below $95 \%$ considered abnormal. Only in 4 (1.6\%) of children was an abnormal result recorded. Neonatal jaundice (above $12 \mathrm{mg} \%$ ), requiring phototherapy, was detected in 40 (15.7\%) patients examined. Congenital infection was diagnosed and treated in $10 \%$ of newborns examined (in 25 patients). Various heart murmurs were auscultated in $15 \%$ of children (38 newborns). In 1 case, arrhythmia was detected and diagnosed as supraventricular extrasystoles. This data is presented in Table 1.

\section{Results of cardiological testing}

Among the group studied, there were 3.5\% (9 patients) with defects of the circulatory system diagnosed, such as intra-atrial septal defect (ASD) in 1 newborn $(<1 \%)$, intraventricular septal defect (VSD) in 4 patients (1.6\%), patent ductus arteriosus (PDA) in 3 newborns (1.1\%), and complex defect consisting of coarctation of the aorta with bicuspid aortic valve and mitral valve insufficiency in 1 patient $(<1 \%)$.

In 38 newborns with loud systolic murmur detected over the heart, only 5 were diagnosed with heart defects - VSD and complex defect consisting of coarctation of the aorta with bicuspid aortic valve and mitral valve insufficiency. The complex heart defect was hemodynamically significant and the child was referred for cardiosurgical intervention.

Moreover, among the group studied, mild hypokinesis of the heart muscle was found in 2 newborns $(<1 \%)$, tricuspid valve insufficiency in 8 newborns (3.1\%), decreased acceleration time of pulmonary flow in 7 newborns $(2.7 \%)$, mild hypertrophy of the intraventricular septum in 3 newborns $(1.1 \%)$, and single supraventricular arrhythmia in 1 newborn $(<1 \%)$. Patent foramen ovale was found in 140 newborns (55.0\%) of which in $50 \%$ of the PFO cases the PFO was $4.0 \mathrm{~mm}$ and in $25 \%$ of cases the PFO was larger than $5 \mathrm{~mm}$. In 14 additional newborns, other small irregularities of the cardiovascular system were detected and assessed as transient in nature.

The assessment of the selected echocardiographic parameters is presented in Table 2 .

In the group studied, the correlation between the measured echocardiographic parameters and body mass, sex, Apgar score, and delivery method and coexistence of neonatal jaundice was analyzed. Infants born naturally and those born through caesarean section presented no difference in measured echocardiographic parameters.

The correlation between Apgar scores at $1 \mathrm{~min}$ and 5 min and dimensions of RV and LV were likewise irrelevant; similarly, functional parameters of the circulatory system did not show relevant correlation with Apgar score in newborns. It may be that this is due to the uniformity of the group assessed (overwhelmingly assessed at $8-10$ points). A relevant weak negative correlation was observed between pulmonary acceleration time and Apgar score after the $1^{\text {st }} \mathrm{min}$ of life (lower level of pulmonary acceleration results in an insignificantly lower Apgar score) while after 5 min of life this correlation disappears, which may be linked to therapeutic efforts (i.e., oxygen therapy) in patients with lower Apgar scores.

Statistical analysis of the size of cavities of RV and LV in dependence on the overall mass of the newborn and sex expressed a weak relevant correlation between the mass of the infant and the dimensions of LV; newborns with a greater body mass had larger dimensions of LV. Little correlation was found between the body mass and the dimensions of RV. The sex of the child has no influence on the size of the LV or RV. A relevant correlation was found between body mass and TAPSE in that its increased value was linked with higher body mass. No effect of neonatal jaundice or the use of phototherapy to treat it was found on the parameters studied on echocardiographic assessment of heart size and function.

The characteristics of mitral influx in the first 2 weeks of life was the same as during fetal life. Mitral valve velocity flow in early diastole was lower than mitral valve velocity flow in late diastole $(\mathrm{MVE}<\mathrm{A})$. In almost half

Table 1. Schedule of abnormalities in infant group examined

\begin{tabular}{|c|c|c|c|}
\hline \multicolumn{2}{|c|}{ Physical examination } & \multicolumn{2}{|c|}{ Echocardiographic examination } \\
\hline type & quantity & morphological & functional \\
\hline Jaundice > 12 mg\% & 15.7\% (40 patients) & PDA < 1\% (1 patient) & hypokinesis LV <1\% (2 patients) \\
\hline Pulse oximetry $\leq 95$ & $1.6 \%$ (4 patients) & multiASD 1.1\% (3 patient) & hypokinesis RV <1\% (1 patient) \\
\hline Congenital infection & 10\% (25 patients) & mVSD 1.6\% (4 patient) & ITV 3.1\% (8 patients) \\
\hline Heart murmur & 15\% (38 patients) & CoAo $<1 \%$ (1 patient) & supraventricle arrhythmia <1\% (1 patient) \\
\hline Arrhythmia & $<1 \%$ (1 patient) & IVS hypertrophy 1.1\% (3 patients) & PulmAT 2.7\% (7 patients) \\
\hline Apgar score 10 points at $5 \mathrm{~min}$ & 99.2\% (253 patients) & PFO 55.0\% (140 patients) & MVE < A 41.6\% (106 patients) \\
\hline
\end{tabular}

PDA - patent ductus arteriosus; multiASD - multi atrial septal defect; mVSD - muscular ventricle septal defect; CoAo - coarctation of aorta; IVS - hypertrophy intraventricle septum hypertrophy; PFO - patent foramen ovale; LV - left ventricle; RV - right ventricle; ITV - tricuspid valve insufficiency; pulmAT - pulmonar acceleration time; MVE - mitral valve velocity flow in early diastole; MVA - mitral valve velocity flow in late diastole. 
Table 2. Schedule of results of morphological and functional parameters examined

\begin{tabular}{|l|c|c|c|c|c|c|}
\multicolumn{1}{|c|}{ Echocardiographic parameters } & Medium & Min & $\mathrm{n}<25$ & $\mathrm{n}=50 \%$ & $\mathrm{n}>25 \%$ & Max \\
\hline RVED $[\mathrm{mm}]$ & 8.5 & 5 & 7 & 8 & 9 & 19 \\
\hline LVED $[\mathrm{mm}]$ & 18.3 & 13 & 17 & 18 & 19 & 27 \\
\hline LVES $[\mathrm{mm}]$ & 12.2 & 8 & 11 & 12 & 13 & 18 \\
\hline PV $[\mathrm{m} / \mathrm{s}]$ & 0.9 & 0.5 & 0.8 & 0.9 & 1 & 1.68 \\
\hline PulmAT $[\mathrm{ms}]$ & 76.8 & 37 & 67 & 74 & 89 & 133 \\
\hline AoV $[\mathrm{m} / \mathrm{s}]$ & 0.98 & 0.16 & 0.8 & 1 & 1 & 1.90 \\
\hline FS $>$ 28\% & 33.7 & 22 & 31 & 33 & 36 & 70 \\
\hline EF $>55 \%$ & 65 & 47 & 61 & 65 & 68 & 80 \\
\hline TAPSE & 10.1 & 5 & 9 & 10 & 11 & 22 \\
\hline
\end{tabular}

RVED - right ventricle in diastole; LVED - left ventricle in diastole; LVES - left ventricle in systole; PV - pulmonary valve; PulmAT - pulmonar acceleration time; AoV - velocity of flow on the aortic; FS - fractional shortening; EF - ejection fraction; TAPSE - tricuspid annular plane systolic excursion.

of the subjects examined but also in a large portion of cases in which mitral valve velocity flow in early diastole was the same as mitral valve velocity flow in late diastole $(\mathrm{MVE}=\mathrm{A})$ or was higher $(\mathrm{MVE}>\mathrm{A})$. No correlation was found between the presence of PFO and Apgar score assessed after $1 \mathrm{~min}$ of life. Additionally, the presence of PFO and incidence of neonatal jaundice and body mass showed no relevant correlation.

Due to the small sample size of neonates with congenital infections, correlation with the functional parameters assessed was not analyzed.

\section{Discussion}

The literature puts an emphasis on the relevance of screening tests in newborns, which help to diagnose diseases which do not present symptomatically directly after birth or whose symptoms are masked. Recently, the test used to screen for CHDs has been pulse oximetry. From the available data gathered through the POLKARD program in the years 2006-2008, assessing the usefulness of pulse oximetry in the diagnosis of CHD in newborns, we can conclude that the sensitivity of this method is $78 \%$ while specificity is $99.9 \%$ and negative predictive value is almost $100 \% .{ }^{10}$ These findings are very similar to the data published by Thangaratinam et al. in 2012 which estimated the sensitivity of the test at $76.5 \%$ and specificity at $99.9 \%$ with the fraction of false positive results being only $0.14 \%{ }^{9}$

In $1.6 \%$ of patients (4 patients), pulse oximetry testing gave false positive results because irregularities in the circulatory system were not confirmed upon further testing. In the population studied, 1 case of hemodynamically relevant $\mathrm{CHD}$ was diagnosed, consisting of a coarctation of the aorta with a bicuspid aortic valve necessitating surgical intervention while the test gave a normal result in the child. Pulse oximetry may not reveal coarctation of the aorta unless the defect is of critical intensity, as in the mentioned case. ${ }^{11}$
In the group of newborns examined, 7 cases $(2.7 \%)$ of simple heart defects were diagnosed with correct pulse oximetry results: 4 cases of muscular ventricle septal defect (mVSD) and 3 cases of patent ductus arteriosus (PDA) which did not require further intervention and in most cases resolved spontaneously. Two children (0.7\%) had defects which required surgical intervention despite proper pulse oximetry test results.

In the group analyzed, the most common finding was patent foramen ovale (PFO); such defect with a diameter of less than $4 \mathrm{~mm}$ was found in $54.9 \%$ of newborns (140 patients), while in only $5 \%$ of patients the size of the PFO was above $5 \mathrm{~mm}$ in diameter and in 1 newborn - of $8 \mathrm{~mm}$.

Fukazawa et al. in their study of the spontaneous closure of defects in the intra-atrial septum, qualified PFO with a diameter greater than 5-6 $\mathrm{mm}$ as an atrial septal defect type II (ASD II). ${ }^{12}$ Newborns with a borderline-sized PFO $(5 \mathrm{~mm})$ were not qualified as having a congenital heart defect (CHD). Diagnosis of ASD II in newborns seems to be controversial due to the fact that this is a physiological structure in the first days of newborn life. ${ }^{13}$ From cardiological observation we know that PFO and the method of its closure varies from patient to patient and may occur gradually or quickly through the PFO valve closure.

Intraventricular septal defect is the most common CHD diagnosed in children and, according to many authors, it makes up from $5 \%$ to even $20 \%$ of all CHDs. ${ }^{14}$ In the analyzed group, 4 incidents of VSD with typical, auscultatable murmurs over the heart with a 3/6 in the Levine scale and proper pulse oximetry test results. Muscular type VSD is a mild form of this heart defect which in most cases does not require intervention, may close spontaneously as the child grows and generally does not produce significant hemodynamic dysfunction. ${ }^{15}$

According to various source data, PDA is recognized as a CHD if its patency is maintained beyond the $4^{\text {th }}$ day of life or, more commonly, beyond the $7^{\text {th }}$ day of life. ${ }^{13,15,16}$ In this study, PDA was diagnosed in only $1.1 \%$ (3) of patients and in all of those the duct closed spontaneously. Other functional dysfunctions visible in echocardiographic 
assessment such as shortened pulmonary flow time, mild tricuspid valve insufficiency and decreased contractility of the cardiac muscle were all transient in nature and may be attributed to the acclimation of newborns to postnatal life.

In the available literature, the data concerning echocardiographic norms of selected structures of the heart and functional parameters come from the 1980s. ${ }^{17}$ Currently, analysis of echocardiographic parameters is carried out based on foreign literature ${ }^{17-23}$ as well as, more often, calculation of the Z-score. ${ }^{20,24,25}$

On the basis of the group studied, we can create norms of selected parameters of the structure and function of the circulatory system in healthy delivered newborns, which may be useful for physicians conducting heart echocardiography in clinics with limited access to cardiological consult.

\section{Conclusions}

Pulse oximetry testing, due to its low level of invasiveness, high sensitivity and specificity, low cost, and repeatability, should be used as the primary screening test allowing for early detection of critical CHDs. It should be stressed that the test should be repeated before discharge of newborns from the neonatology department so as to avoid missing CHDs which are asymptomatic or mute at birth.

Morphological and functional assessment of specific structures of the heart in delivered newborns born in basic level perinatal care centers showed correlation of the size of LV with body mass. The remaining factors, such as method of delivery, sex, neonatal jaundice, and audible murmur, were irrelevant.

Routine cardiological assessment of healthy newborns is not necessary. Cardiological testing as a screening method for newborns should not be recommended.

\section{References}

1. Ministerstwo Zdrowia. Program polityki zdrowotnej. Program badań przesiewowych noworodków w Polsce na lata 2015-2018. Warszawa, Poland: Ministerstwo Zdrowia; 2017.

2. Stanek B, Binikowska J, Moll J, Sysa A. Wrodzone nieprawidłowości układu krążenia u noworodków urodzonych w Instytucie Zdrowia Matki Polki w Łodzi w latach 1998-2004. Post Neonatol. 2004;Suppl 2: 14-17.

3. Kirshnamurthy G, Ratner V, Levasseur S, Rubenstein D. Wrodzone wady serca w okresie noworodkowym. Neonatologia w praktyce. Warszawa, Poland: MediPage; 2015:256.

4. Peterson C, Grosse SD, Glidewell J, et al. A public health economic assessment of hospitals' cost to screen newborns for critical congenital heart disease. Public Health Rep. 2014;129(1):86-93.

5. Gadzinowski J, Gruszfeld D, Czech-Kowalska J. Organizacja opieki nad noworodkiem w skali regionalnej. Standardy opieki medycznej nad noworodkiem w Polsce. Zalecenia Polskiego Towarzystwa Neonatologicznego. $2^{\text {nd }}$ ed. Warszawa, Poland: Media-Press; 2017:12-16.
6. Brand A, Alves MC, Saraiva CL. Fetus in fetu: Diagnostic criteria and differential diagnosis. A case report and literature review. J Pediatr Surg. 2004;39(4):616-618.

7. Mroziński B, Siwińska A, Sobkowski W, Maciejewski J. Wrodzone wady układu krążenia u noworodków i niemowląt diagnozowanych w pracowni echokardiograficznej Kliniki Chorób Dzieci Instytutu Pediatrii Akademii Medycznej im. Karola Marcinkowskiego w Poznaniu w latach 1995-1999. Post Neonatol. 2000;Suppl 1;119-123.

8. Rozporządzenie Ministra Zdrowia z dnia 20 września 2012 r. (Dz. U. z dnia 4.10.2012 r. Nr 189, poz. 1100).

9. Thangaratinam S, Brown K, Zamora J, Khan KS, Ewer AK. Pulse oximetry screening for critical congenital heart defects in asymptomatic newborn babies: A systematic review and meta-analysis. Lancet. 2012; 379(9835):245-264.

10. Kawalec W, Turska-Kmieć A, Żuk M, et al. Poprawa opieki kardiologicznej nad dzieckiem z patologią układu krążenia ze szczególnym uwzględnieniem oceny wyników leczenia i lepszej jakości życia dzieci z wrodzonymi wadami serca. Ogólnopolski program wielozadaniowy i wieloośrodkowy realizowany w ramach programu POLKARD 2006-2008. Stand Med Pediatr. 2009;6:614-622.

11. Błaż W, Turska-Kmieć A. Pulsoksymetria jako metoda wykrywania wad wrodzonych serca u bezobjawowych noworodków. Pediatr Dypl. 2010;14(4):107-112.

12. Fukazawa M, Fukushige J, Veda K. Atrial septal defect in neonates with references to spontaneous closure. Am Heart J. 1988;116(1 Pt 1): 123-127.

13. Sachdeva R. Congenital cardiovascular malformations; Atrial septal defects. In: Allen HD, Driscoll DJ, Shaddy RE, Feltes TF, eds. Moss and Adams' Heart Disease in Infants, Children, and Adolescents: Including the Fetus and Young Adult. Vol 1.8th ed, Philadelphia, PA; Lippincott Williams \& Wilkins. 2013:683-688.

14. Soto B, Becker AE, Moulaert AJ, Lie JT, Anderson RH. Classification of ventricular septal defects. Br Heart J. 1980;43(3):332-343.

15. Kubicka K, Kawalec W, Bernatowska E. Pediatria. Warszawa, Poland: Wydawnictwo Lekarskie PZWL; 2004:311-317.

16. Andreson RH, Macartney FJ, Shinebourne EA, et al. Paediatric Cardiology. $2^{\text {nd }}$ ed. London, UK: Churchill Livingstone; 2002:278-284.

17. Biamino G, Lange L. Echokardiographie-Stellenwert in der kardiologischen Diagnostik. Frankfurt am Main, Germany: Hoechst Verlag; 1983:134-138.

18. Cantinotti M, Scalese M, Murzi B, Murzi B, Passino C. Echocardiographic nomograms for chamber diameters and areas in Caucasian children. J Am Soc Echocardiogr. 2014;27(12):1279-1292.e2.

19. Cantinotti M, Scalese M, Molinaro S, Murzi B, Passino C. Limitations of current echocardiographic nomograms for left ventricular, valvular, and arterial dimensions in children: A critical review. J Am Soc Echocardiogr. 2012;25(2):142-152.

20. Siwińska A, Werner B, Rudziński A, et al; Echocardiography Working Group of the Polish Cardiology Society. Paediatric echocardiography in clinical practice. 2012 Recommendations of the Echocardiography Working Group of the Polish Cardiac Society [in Polish]. Kardiol Pol. 2012;70(6):632-640.

21. Kampmann C, Wiethoff CM, Wenzel A, et al. Normal values of M mode echocardiographic measurements of more than 2000 healthy infants and children in central Europe. Heart. 2000;83(6):667-672.

22. Lopez L, Colan SD, Frommelt PC, et al. Recommendations for quantification methods during the performance of a pediatric echocardiogram: A report from the Pediatric Measurements Writing Group of the American Society of Echocardiography Pediatric and Congenital Heart Disease Council. J Am Soc Echocardiogr. 2010;23(5):465-95

23. Mawad W, Drolet C, Dahdah N, Dallaire F. A review and critique of the statistical methods used to generate reference values in pediatric echocardiography. J Am Soc Echocardiogr. 2013;26(1):29-37.

24. Colan SD. The why and how of Z-scores. J Am Soc Echocardiogr. 2013; 26(1):38-40.

25. Gokhroo RK, Anantharaj A, Bisht D, Kishor K, Plakkal N, Mondal N. A pediatric echocardiographic Z-score nomogram for a developing country. Indian pediatric echocardiography study: The Z-score. Ann Pediatr Cardiol. 2017;11(1):109-111. 